\title{
Effect of Regulated Deficit Irrigation on Productivity, Quality and Water Use in Olive cv "Manzanilla”
}

\author{
Raúl Leonel Grijalva-Contreras $^{{ }^{*}}$, Rubén Macías-Duarte ${ }^{1}$, Gerardo Martínez-Díaz ${ }^{1}$, \\ Fabián Robles-Contreras ${ }^{1}$, Manuel de Jesús Valenzuela-Ruiz ${ }^{1}$, Fidel Nuñez-Ramírez ${ }^{2}$ \\ ${ }^{1}$ National Research Institute for Forestry, Agricultural and Livestock (INIFAP), Caborca, Sonora, México; ${ }^{2}$ Agricultural Science \\ Institute, University Autónoma of Baja California (ICA-UABC), Mexicali, B.C. México. \\ Email: *rgrijalva59mx@hotmail.com
}

Received October $26^{\text {th }}, 2013$; revised November $29^{\text {th }}, 2013$; accepted December $18^{\text {th }}, 2013$

Copyright (C) 2013 Raúl Leonel Grijalva-Contreras et al. This is an open access article distributed under the Creative Commons Attribution License, which permits unrestricted use, distribution, and reproduction in any medium, provided the original work is properly cited.

\begin{abstract}
The objective of this experiment was to determine the effect of different regulated deficit irrigation (RDI) strategies on productivity, oil quality and water-use efficiency on olive grown in the Sonoran Desert. The experiments were carried out in 2009 and 2010, and in a ten years old traditional $(10 \times 5 \mathrm{~m})$ "Manzanilla" olive orchard. The control treatment was irrigated at $100 \%$ ETc during the whole season while RDI treatments were applied at $75 \%$ ETc or 50\% ETc. The two RDI were applied during two phenological stages: at postharvest to evaluate the effect on table olive or from pit hardening to harvest to evaluate the effect on oil olive. Our results indicated that RDI applying 50\% ETc during postharvest period reduced significantly fruit set and table olive yield, while applied during pit hardening to harvest period, it decreased oil yield but increased oil content. The RDI applying an ETc of $75 \%$ during the postharvest period gave similar table olive yield to the control, and applied form of pit hardening to harvest also gave similar oil yield to the control. The RDI using an ETc of 75\% resulted in the highest water-use efficiency for oil or table olive production.
\end{abstract}

Keywords: Olea europaea L.; Water Stress; Yield and Quality; Water Save

\section{Introduction}

Mexico has about 9000 ha cultivating olive tree, where almost $50 \%$ Mexican are located in the arid and semiarid regions. Caborca and Sonora, the main areas of table olive producer in México, have about 2000 ha planted with this tree and produce approximately 10,000 ton annually, all of which are exported to United State [1].

The climate conditions are characterized by low precipitation (100 to $150 \mathrm{~mm}$ per year) occurring mainly during the summer months-high temperature and low atmospheric humidity. These conditions result in an annual ETo of $2200 \mathrm{~mm}$ which determines a high water demand by crops [2].

The contribution of precipitation to the water demand of olive trees is insignificant and basically the crop depends exclusively on irrigation. The sustainability of olive production in the area requires improving the crop's water productivity.

\footnotetext{
${ }^{*}$ Corresponding author.
}

Regulated deficit irrigation (RDI) causes a temporary and controlled water deficit in a specific phenological stage. RDI is commonly used in several fruit trees in order to reduce the amount of water applied with minimal or no reduction in fruit production [3]. For olive trees, the second phase of fruit growth, corresponding to the pit hardening period, is the most resistant to water deficit [4]. In the first phase, fruit growth corresponds, when most cell division occurs, and in the third phase, when the olive oil is accumulated, it is sensitive to water stress $[5,6]$.

Some studies indicate that RDI did not affect the yield fruit and fruit weight [7,8], acidity and peroxide value [9]; however it increases oil content, polyphenol concentration and oil stability [7,10]. On the other hand, RDI reduced flowering next year [11] and accelerated ripening [12]. The response to RDI depends on the olive variety [13]. Little information is available about RDI effects on table olive and oil olive quality of the Manzanilla cultivar which is grown in the arid warm climates.

The objective of this work was to determine the effect 
of different RDI strategies on productivity, oil quality and water-use efficiency in the cv Manzanilla.

\section{Materials and Methods}

\subsection{Orchard Selection and Management}

The experiments were carried out in 2009 and 2010 at the National Research Institute for Forestry, Agricultural and Livestock (INIFAP), located in Caborca, Sonora, Mexico ( $30^{\circ} 42^{\prime} 55^{\prime \prime} \mathrm{N}, 112^{\circ} 21^{\prime} 28^{\prime \prime} \mathrm{W}$ and $200 \mathrm{~m}$. a. s. 1.), in a ten years old traditional $(10 \times 5 \mathrm{~m})$ "Manzanilla" olive orchard. The soil was sandy loam with $\mathrm{pH} 7.96$ and electrical conductivity of $1.22 \mathrm{dSm}^{-1}$. Olive trees were maintained in accordance to commercial recommendations [1]. The trees were drip irrigated by using two emitters for tree $\left(12.0 \mathrm{~L} \cdot \mathrm{ha}^{-1}\right)$. Orchard olive was fertilized in both years with $15-15-15$ at a rate of $1.5 \mathrm{~kg}$ tree $\mathrm{e}^{-1}\left(468 \mathrm{~kg} \cdot \mathrm{ha}^{-1}\right)$ during February and March and with ammonium nitrate $\left(300 \mathrm{~kg} \cdot \mathrm{ha}^{-1}\right)$ during the postharvest period. The trees were slightly pruned in November in both years. Table olive was harvested during last week of August and the oil olive was harvested during second week of September. Both harvests were made manually.

\subsection{RDI Treatments Applied}

Different irrigation treatments, based on RDI strategies were applied in 2009 and 2010. The first experiment consisted in the following treatments: 1) Control $(100 \%$ ETc), 2) RDI-75 and 3) RDI-50. RDI-2 consisted in applying an ETc of $75 \%$ from the second week of August to the third week of November 2009 (postharvest), and $\mathrm{RD}-3$ in applying an ETc of 50\% in the same period. The second experiment, conducted in 2010, had the same treatments but the period of water restriction was from third week of May to last week of September, the period from the pit hardening to harvest. In both experiments the cultivar was Manzanilla but in the first experiment was for table olive and in the second experiment for oil olive. ETo was calculated every week based on the meteorological data using an automatic station (Campbell Scientific Ltd., Shepshed, UK) during the whole season.

\subsection{Measurement Variable}

In the first Experiment the vegetative parameters plant height, shoot length and width canopy were evaluated taking 12 trees per treatment, in mid November of each season. Yield components as floral density floral (flower per $\mathrm{cm}^{-2}$ ) and fruit set (\%), choosing one floral shoot per each side of the tree was also evaluated. Yield $\left(\mathrm{kg} \mathrm{tree}^{-1}\right)$ of table olive and quality fruit were evaluated. Fruit weight, fruit diameter, fruit length and pulp and pit ratio were evaluated taking a random sample of 100 fruits for each tree. Water use efficiency was obtained according the next equation: WUE $=$ Yield $\mathrm{kg} \cdot \mathrm{ha}^{-1} /$ water applied $(\mathrm{mm})$. In the second experiment similar variables were evaluated but in addition, fruit oil percentage was measured according to $[14,15]$ and some parameters of oil quality as acidity (\% oleic acid), peroxide value (meq. of $\mathrm{O}_{2}$ per $\mathrm{kg}$ ) and total polyphenols (ppm of caffeic acid) as described by $[15,16]$. Also, we recorded weather pa- rameters during both experiments (Table 1).

\subsection{Statistical Analysis}

Experimental design in both years was a randomized complete block and four replications with an experimental unit of 12 trees. Means were separated with the least significant difference test (LSD) at 0.05 probability level.

\section{Results and Discussion}

\subsection{Experiment 1}

\subsubsection{Vegetative Parameters and Yield Components}

RDI strategies during the period of postharvest did not affect significantly plant height, shoot length and canopy size (Table 2). Fruit set was statistically affected ( $<<$ 0.05 ) while the density flower was not (Table 3). The fruit set percent in Control and RDI-75 was similar (1.43\% and $1.38 \%$ respectively), while in RDI-50 was statistically reduced to $1.25 \%$. These results do not agree with Tognetti et al. [17] who found that RDI at $50 \%$ decreased canopy volume and trunk diameter in Koroneiki cultivar. Other study of water stress indicated that a $\mathrm{Kc}$ of $75 \%$ and $50 \%$ decreased $8.6 \%$ height plant and $14.2 \%$ trunk diameter with respect to control (Kc 100\%) in Manzanillo cultivar of six years old [18]. The reduction of

Table 1. Weather parameters recorded during the study period.

\begin{tabular}{ccc}
\hline Weather parameters & Experiment 1 & Experiment 2 \\
\hline Medium temperature $\left({ }^{\circ} \mathrm{C}\right)$ & 21.9 & 30.0 \\
Rainfall $(\mathrm{mm})$ & 17.8 & 74.4 \\
Relative humidity $(\%)$ & 38.7 & 38.9 \\
Solar radiation (Kilowatt. $\mathrm{m}^{-2}$ ) & 0.153 & 0.206 \\
\hline
\end{tabular}

Table 2. Vegetative growth parameters in different RDI applied during postharvest on table olive.

\begin{tabular}{cccc}
\hline Treatments & $\begin{array}{c}\text { Plant height } \\
(\mathrm{m})\end{array}$ & $\begin{array}{c}\text { Shoot length } \\
(\mathrm{cm})\end{array}$ & $\begin{array}{c}\text { Canopy width } \\
(\mathrm{m})\end{array}$ \\
\hline Control & $5.1 \pm 0.26$ & $25 \pm 1.87$ & $4.2 \pm 0.21$ \\
RDI-75 & $5.0 \pm 0.19$ & $25 \pm 3.53$ & $4.1 \pm 0.26$ \\
RDI-50 & $4.7 \pm 0.12$ & $23 \pm 2.55$ & $3.8 \pm 0.14$ \\
Significance & $\mathrm{ns}$ & $\mathrm{ns}$ & $\mathrm{ns}$ \\
\hline
\end{tabular}

Means followed by same letter in a column do not differ significantly (LSD $0.05)$; ns = non significant. 
Table 3. Yield components in different RDI applied on table olive.

\begin{tabular}{ccc}
\hline Treatments & Floral density $\left(\right.$ flowers $\left.\mathrm{cm}^{-2}\right)$ & Fruit set (\%) \\
\hline Control & $3240 \pm 530$ & $1.43 \pm 0.06 \mathrm{a}$ \\
RDI-75 & $2950 \pm 337$ & $1.38 \pm 0.02 \mathrm{a}$ \\
RDI-50 & $3100 \pm 420$ & $1.25 \pm 0.08 \mathrm{~b}$ \\
Significance & $\mathrm{ns}$ & $*$
\end{tabular}

Means followed by same letter in a column do not differ significantly (LSD $0.05) ; \mathrm{ns}=$ non significant; ${ }^{*}$ Significant at 0.05 probability level.

vegetative growth could reduce pruning cost [17]. Floral density was not statistically different among RDI treatments while fruit set percent decreased as the water was reduced. Fruit set for Control and RDI-75 were similar with values of $1.43 \%$ and $1.38 \%$, while for RDI-50 was reduced to $1.25 \%(\mathrm{p}<0.05)$ with. Other researchers [19] indicated that water stress during whole season decreased drastically fruit set on Koroneiki cultivar when ETc were $50 \%$ and $25 \%$. Grattan et al. [20] found the number of fruits per branch, the number of fruits per inflorescence, fruit density and fruit set increased with an increase of ETc up to $71 \%-89 \%$.

\subsubsection{Table Olive Yield and Fruit Quality}

According to Table 4 there is significant difference among RDI tested on table olive yield $(\mathrm{p}<0.01)$, fruit weigh $(\mathrm{p}<0.01)$ and fruit diameter $(\mathrm{p}<0.05)$. The higher yield was obtained in Control and RDI-75 with 11,040 and $10,280 \mathrm{~kg} \cdot \mathrm{ha}^{-1}$ without statistical difference between them, while RDI-50 had reduction on the table olive yield of $28.6 \%$ and $21.3 \%$ in comparison with Control and RDI-75, respectively. The low yield in RDI-50 was due to a lower fruit set in this treatment. Goldhamer [8] found that a reduction of $15 \%$ and $25 \%$ in water supply during midsummer, did not have a negative impact on canning olive yield, but a reduction by $44 \%$, decreased yield by $10 \%$. Others studies indicated different effects on yield when RDI was imposed and the responses were different among years [7]. Weight and fruit diameter were similar between the control and RDI-75. In both parameters RDI-50 was the better treatment and statistically different to control and RDI-75\%. Fruit weight in RDI-50 was $12.2 \%$ and $8.1 \%$ greater in comparison to the control and RDI-75, respectively, and fruit diameter in RDI-50 was $11.1 \%$ greater than the other treatments. The differences in fruit weight and fruit diameters may be due to the different fruit load among treatments. Moriana et al. [5] found that fruit weight decreased drastically in response to the level of water stress and fruit load. During severe deficit irrigation, fruit diameter growth slowed; however, after reintroduction of full irrigation, growth accelerated [21]. RDI did not significantly affect pulp and pit ratio.

\subsection{Experiment 2}

\subsubsection{Oil Yield and Oil Content}

There were statistical difference $(\mathrm{p}<0.01)$ among treatments in oil yield and oil content when RDI strategies were applied during pit hardening to harvest period in the same variety. Oil production per hectare in RDI-75 was $26.5 \%$ and $10.4 \%$ less in comparison with the Control and RDI-50, respectively. In contrast, the oil content was higher in RDI-50 with $8.7 \%$ and $9.6 \%$ more that Control and RDI-75, respectively (Table 5). The high oil content in RDI-50 is probably as a consequence of lower water content in the olive. Vita et al. [7] found that RDI at 50\% ETc applied in the same period decreased $26 \%$ oil yield. However, other studies indicated not differences in oil yield when RDI was imposed [12,22]. Goldhamer et al. [23] found that oil content was significantly higher for all RDI strategies applied in comparison to the control, and the most severely stressed had an increase in oil content about $30 \%$.

\subsubsection{Oil Quality}

No statistical differences among treatments on peroxide value, acidity and total polyphenols were found in the experiment (Table 6). Total polyphenols was increased as the amount of supplied water decreased, although without statistical difference. These results are accordance with those previously reported in Arbequina variety $[7,9,10]$.

\subsubsection{Water Use Efficiency}

The amount of water applied in postharvest period in RDI-75 was $215.8 \mathrm{~mm}$ while in the control it was 431.6 $\mathrm{mm}$, in the first experiment. In the second experiment the RDI-75 received $325 \mathrm{~mm}$ and the control $650.1 \mathrm{~mm}$ of water from pit hardening to harvest. Water use efficiency (WUE) measured as fruit yield or oil yield $(\mathrm{kg})$ per $\mathrm{mm}$ of irrigation water, was greater for both periods when RDI-75 was applied, reaching values of 0.83 during pit hardening to harvest period (Table 7). These values are less that those reported by Vita et al. [7] for a six years old intensive Arbequina olive orchard. By other side, RDI-75 could save until $12.4 \%$ (163 mm) when RDI is applied during pit hardening to harvest period. Goldhamer [8] suggests that the RDI regime that saves about $25 \%(200 \mathrm{~mm})$ of full ETc may be useful in conserving water while maintaining top yield and high fruit quality.

\section{Conclusion}

A regulated deficit irrigation applying 75\% ETc during the postharvest period allows saving water without affecting table olive yield and quality, while the same wa- 
Table 4. Olive table yield and fruit quality in different RDI applied during postharvest.

\begin{tabular}{ccccc}
\hline Treatments & Yield $\left(\mathrm{kg} \cdot \mathrm{ha}^{-1}\right)$ & Fruit weight $(\mathrm{g})$ & Fruit diameter $(\mathrm{cm})$ & Pulp-pit ratio \\
\hline Control & $11040 \pm 2212 \mathrm{a}$ & $4.3 \pm 0.26 \mathrm{~b}$ & $1.6 \pm 0.08 \mathrm{~b}$ & $3.9 \pm 0.12$ \\
RDI-75 & $10280 \pm 1520 \mathrm{a}$ & $4.5 \pm 0.22 \mathrm{~b}$ & $1.6 \pm 0.07 \mathrm{~b}$ & $3.8 \pm 0.08$ \\
RDI-50 & $7920 \pm 11230 \mathrm{~b}$ & $4.9 \pm 0.18 \mathrm{a}$ & $1.8 \pm 0.07 \mathrm{a}$ & $3.8 \pm 0.10$ \\
Significance & $* *$ & $* *$ & $*$ & $\mathrm{~ns}$ \\
\hline
\end{tabular}

Means followed by same letter in a column do not differ significantly (LSD 0.05); ns = non significant; ${ }^{*}$ Significant at 0.05 probability level and ${ }^{* *}$ Significant at 0.01 probability level.

Table 5. Oil yield and oil content in different RDI applied during pit hardening to harvest period.

\begin{tabular}{ccc}
\hline Treatments & Oil yield $\left(\mathrm{kg} \cdot \mathrm{ha}^{-1}\right)$ & Oil content $(\%)$ \\
\hline Control & $1020 \pm 71.2 \mathrm{a}$ & $10.5 \pm 0.22 \mathrm{~b}$ \\
RDI-75 & $956 \pm 62.5 \mathrm{a}$ & $10.6 \pm 0.24 \mathrm{~b}$ \\
RDI-50 & $750 \pm 55.3 \mathrm{~b}$ & $11.5 \pm 0.21 \mathrm{a}$ \\
Significance & $* *$ & $* *$ \\
\hline
\end{tabular}

Means followed by same letter in a column do not differ significantly (LSD 0.05 ); ${ }^{* *}$ Significant at 0.01 probability level.

Table 6. Oil quality in different RDI applied during pit hardening to harvest period.

\begin{tabular}{cccc}
\hline Treatments & Peroxide value $\left(\mathrm{meq} \mathrm{O}_{2 \mathrm{f}}{ }^{-1}\right)$ & Acidity (\% oleic acid) & Polyphenols (ppm of caffeic acid) \\
\hline Control & $15.2 \pm 0.90$ & $0.45 \pm 0.02$ & $153 \pm 12.8$ \\
RDI-75 & $14.8 \pm 0.59$ & $0.48 \pm 0.01$ & $174 \pm 14.3$ \\
RDI-50 & $15.6 \pm 0.73$ & $0.43 \pm 0.02$ & $180 \pm 22.0$ \\
Significance & $\mathrm{ns}$ & $\mathrm{ns}$ & $\mathrm{ns}$ \\
\hline
\end{tabular}

Means followed by same letter in a column do not differ significantly (LSD 0.05); ns = non significant.

Table 7. Water applied and water use efficiency (WUE) during postharvest period and pit hardening to harvest period.

\begin{tabular}{ccccc}
\hline \multirow{2}{*}{ Treatments } & \multicolumn{2}{c}{ Experiment 1 } & \multicolumn{2}{c}{ Experiment 2 } \\
\cline { 2 - 5 } & Water applied $(\mathrm{mm})$ & WUE $\left(\mathrm{kg}\right.$ of fruit. $\left.\mathrm{mm}^{-1}\right)$ & Water applied $(\mathrm{mm})$ & WUE $\left(\mathrm{kg} \mathrm{of} \mathrm{oil.} \mathrm{mm}^{-1}\right)$ \\
\hline Control & 1416.4 & 7.79 & 1305.0 & 0.78 \\
RDI-75 & 1308.5 & 7.85 & 1142.5 & 0.83 \\
RDI-50 & 1200.6 & 6.60 & 980.0 & 0.76 \\
\hline
\end{tabular}

ter application from pit hardening to harvest also saves water without affecting oil yield. Under that water management, the highest water-use efficiency was achieved in this study.

\section{REFERENCES}

[1] G. C. R. Leonel, F. F. Adán, N. A. J. A. Cristobal and L. C. Arturo, "El Cultivo del Olivo Bajo Condiciones Desérticas del Norte de Sonora," INIFAP-CIRNO-CECAB, Folleto Técnico No. 41, 2010.

[2] J. A. Ruíz Corral, G. Medina García, J. Grageda Grageda, M. M. Silva Serna and G. Díaz Padilla, "Estadísticas Clima- tológicas Básicas del Estado de Sonora (Periodo 19612003)," Libro Técnico No. 1, INIFAP-CIRNO-SAGAR PHA, 2005, pp. 92-93.

[3] M. H. Behboudian, "Deficit Irrigation in Deciduos Orchard," Horticultural Review, Vol. 21, 1997, pp. 105-131.

[4] D. Goldhamer, J. Dunai, L. Ferguson, L. Lavee and I. Klein, "Irrigation Requirement of Olive Trees and Response to Sustained Deficit Irrigation," Acta Horticulturae, Vol. 356, 1994, pp. 172-175.

[5] A. Moriana, D. Pérez-López, A. Gómez-Rico, M. Salvador, N. Olmedilla, F. Ribas and G. Fregapane, "Irrigation Scheduling for Traditional, Low Density Olive Orchard: Water Relation and Influence on Oil Characteristic," Ag- 
ricultural Water Management, Vol. 87, No. 2, 2007, pp. 171-179.

http://dx.doi.org/10.1016/j.agwat.2006.06.017

[6] S. Lavee and M. Woodner, "Factor Affecting the Nature of Oil Accumulation in Fruit of Olive (Olea europaea L.) Cultivars," Journal of Horticultural Science, Vol. 66, No. 5, 1991, pp. 583-591.

[7] F. Vita Serman, D. Pacheco, A. Olguín Pringles, L. Bueno, A. Carelli and F. Capraro, "Effect of Regulated Deficit Strategies on Productivity, Quality and Water Use Eddiciency in a High-Density 'Arbequina' Olive Orchard Located in an arid Region of Argentina," Acta Horticulturae, Vol. 888, 2011, pp. 81-88.

[8] D. Goldhamer, "Regulated Deficit Irrigation for California Canning Olives," Acta Horticulturae, Vol. 474, 1999, Vol. 369-372.

[9] M. J. Motilva, M. P. Romero, S. Alegre and J. Girona, "Effect of Regulated Deficit Irrigation in Olive Oil Production and Quality," Acta Horticulturae, Vol. 474, pp. 377-380.

[10] M. J. Motilva. M. J. Tovar, M. P. Romero, S. Alegre and J. Girona, "Influence of Regulated Irrigation Strategies Applied to Olive Trees (Arbequina cultivar) on Oil Yield and Composition during the Fruit Ripening Period," Journal of the Science of Food and Agriculture, Vol. 80, No. 14, 2000, pp. 2037-2043.

http://dx.doi.org/10.1002/1097-0010(200011)80:14<2037 $\because$ AID-JSFA733>3.0.CO;2-0

[11] S. Alegre, J. Marsal, M. Mata, A. Arbonés, J. Girona and M. J. Tovar, "Regulated Deficit Irrigation in Olive Trees (Olea europaea L. Cv Arbequina) for Oil Production," Acta Horticulturae, Vol. 586, 2002, pp. 259-262.

[12] S. Alegre, J. Girona, J. Marsal, A. Arbonés, M. Mata, D. Montagut, F. Teixidó, M. J. Motilva and M. P. Romero, "Regulated Deficit Irrigation in Olive Trees," Acta Horticulturae, Vol. 474. 1999, pp. 373-376.

[13] M. Patumi, R. Dandria, G. Fontanazza, G. Morelli, P. Giori and G. Sorentino, "Yield and Oil Quality of Intensive Trained Trees of Three Cultivars of Olive (Olea europaea L.) under Different Irrigation Regimens," Journal of Horticultural Science and Biotechnology, Vol. 74, No. 6, 1999, pp. 729-737.

[14] Association of Official Agricultural Chemist (AOAC), "Official Methods of Analysis," 14th Edition, Benjamin
Franklin Station, Washington DC, 1985, pp. 490-576.

[15] European Union Commission Regulation EEC 2568/91 on the Characteristics Methods of Olive Oils and Their Analytical Methods. Official Journal Communities, 1995.

[16] A. Carrasco-Pancorbo, L. Cerratini, A. Bendini, A. SeguraCarretero, T. Gallina-Toschi and A. Fernandez, "Analytical Determination of Polyphenols in Olive Oil," Journal of Separation Science, Vol. 28, No. 9-10, 2005, pp. 837858. http://dx.doi.org/10.1002/jssc.200500032

[17] R. Tognetti, R. D'Andia, R. Laurini and G. Morelli, “The Effect of Deficit Irrigation on Crop Yield and Vegetative Development of Olea europaea L. cvs. Frantoio and Leccino," European Journal of Agronomy, Vol. 25, No. 4, 2006, pp. 356-364. http://dx.doi.org/10.1016/j.eja.2006.07.003

[18] A. Fimbres and M. Castillo, "Comparación y Optimización del Riego por Goteo y Microaspersión en Árboles de Olivo," Biotecnia, Vol. 6, No. 2, 2005, pp. 43-50.

[19] J. Nikbakht, M. Thaeri and M. Sakkaki, "Effect of Continuous Deficit Irrigation on Yield and Quality of Koroneiki Olive (Olea europaea L.) Cultivar," $21^{\text {st }}$ International Congress on Irrigation and Drainage, Teheran, 2011, pp. 356-364.

[20] S. R. Grattan, M. J. Berenguer, J. H. Connel, V. S. Polito and P. M. Vossen, "Olive Oil Production as Influenced by Different Quantities of Applied Water," Agricultural Water Management, Vol. 85, No. 1-2, 2006, pp. 133-140. http://dx.doi.org/10.1016/j.agwat.2006.04.001

[21] D. Goldhamer and R. E. Beede, "Effect of Water on Olive Tree Performance," In: G. T. Sibbett and L. Ferguson, Eds., Olive Production Manual, 2nd Edition, University of California, Agriculture and Natural Resources, Berkeley, Publication 3353, pp. 71-74.

[22] A. Gómez-Rico, M. D. Salvador, A. Moriana, D. Pérez, N. Almedilla, F. Ribas and G. Fregapane, "Influence of Different Irrigation Strategies in a Traditional Carnicabra cv. Olive Orchard on Virgen Olive Oil Composition and Quality," Food Chemistry, Vol. 100, No. 3, 2007, pp. 568-578. http://dx.doi.org/10.1016/j.foodchem.2005.09.075

[23] D. A. Goldhamer, J. Dunai and L. Ferguson, "Irrigation Requirements of Olive Trees and Responses to Sustained Deficit Irrigation," Acta Horticulturae, Vol. 356, 1994, pp. 172-175. 